\title{
HOMESCHOOLING: Sebuah Pendidikan Alternatif
}

\author{
Muh. Ilyas Ismail \\ Fakultas Tarbiyah dan Keguruan UIN Alauddin Makassar \\ Kampus II: Jalan Sultan Alauddin Nomor 36 Samata-Gowa \\ Email: iilyasismail@yahoo.co.id
}

\begin{abstract}
Abstrak:
Tulisan ini bertujuan untuk mengkaji konsep teoritik, klasifikasi, dan pelaksanaan homeschooling di Indonesia. Pembahasan Homeschooling ini adalah dalam perspektif perkembangan anak. Kesimpulan hasil kajian secara teoritik adalah bahwa Homeschooling adalah pendidikan yang dilakukan secara mandiri oleh keluarga, yang materi pembelajarannya dipilih dan disesuaikan dengan kebutuhan anak. Klasifikasi format homeschooling terbagi dua yaitu Homeschooling tunggal yang dilaksanakan oleh orangtua dalam satu keluarga tanpa bergabung dengan lainnya, dan homeschooling majemuk dilaksanakan oleh dua atau lebih keluarga untuk kegiatan tertentu sementara kegiatan pokok tetap dilaksanakan oleh orangtua masing-masing. Homeschooling merupakan pendidikan bagi anak-anak yang dilaksanakan di rumah dan secara khusus diberikan oleh orang tua atau seorang tutor profesional. Homeschooling dalam praktiknya memindahkan sekolah dari area umum ke area yang lebih privat, yakni ke rumah.
\end{abstract}

\begin{abstract}
:
This article aims to examine the theoretical concept, classification, and the implementation of homeschooling in Indonesia. The discussion of homeschooling was in the perspective of child development. The conclusion based on the theoretical concept describes that it was an educational form which was done independently by family, and the learning materials were choosen in accordance with the children need. The homeschooling classification forms was divided into two forms namely single home schooling which was conducted independently by parents in one family withought collaborating with aothers.Compound homeschooling was conducted by two or more families for certain activities, but the main activities remain to be implemented by the respective parents. Homeschooling was an education for the children who performed at home and was specifically provided by a parent or a professional tutor. Homeschooling in practice was to move the school from the public area to a more private area, which was home.
\end{abstract}

\section{Kata Kunci:}

Homeschooling, perkembangan anak, pendidikan alternatif

KESULITAN mencari sekolah ideal bagi anak menjadi isu yang sering diperbincangkan belakangan ini di kalangan orangtua yang memiliki anak usia sekolah. Tak dapat dipungkiri bahwa standar sekolah ideal yang diinginkan para orangtua maupun pemerhati pendidikan menjadi semakin sulit untuk ditemukan.

Sebagian orang berpendapat bahwa sekolah merupakan satu-satunya pusat pendidikan karena sekolah merupakan lembaga yang diperuntukkan secara khusus bagi pendidikan. Kenyataan menunjukkan terdapat banyak pusat pendidikan seperti 
keluarga, tetangga, kampung halaman, lingkungan, sekolah, masjid, tempat-tempat pertemuan, media massa (seperti surat kabar, radio, dan televisi), dan lain-lain yang berpengaruh secara langsung maupun tidak langsung terhadap pendidikan dan pembentukan kepribadian individu. ${ }^{1}$ Namun tetap saja masyarakat masih menganggap sekolah sebagai satu-satunya sarana pendidikan yang sangat ampuh untuk memperoleh pendidikan.

Pendidikan merupakan suatu aktivitas untuk mengembangkan seluruh aspek kepribadian manusia yang berjalan seumur hidup. Oleh karena itu, pendidikan tidak harus didapat melalui bangku sekolah saja. Sebagian masyarakat yang kritis terhadap lembaga pendidikan formal berpendapat bahwa sekolah itu mengungkung dan menjajah anak. Banyak anak yang secara potensial dapat berpikir mendalam, kreatif, dan memiliki sikap sopan santun, kemudian berubah drastis setelah masuk sekolah. Anak-anak dipaksa belajar apa saja dalam tempo yang telah ditetapkan dan diikat dengan belenggu kurikulum yang ketat hanya untuk mengejar skor tertentu yang ditetapkan sebagai batas kelulusan dalam Ujian Nasional (UN). Keadaaan demikian membuat anak akan merasa dan mengalami tekanan ketika potensi itu tidak tersalurkan di tempat yang benar.

Ungkapan di atas sejalan dengan yang dialami oleh seorang anak usia 15 tahun bernama M. Izza Ahsin yang merasa dirinya terpenjara dalam sekolah formal. Hal ini karena ia mempunyai bakat untuk menulis yang tidak dapat tersalurkan dan diasah bila ia terus berada dalam sekolah formal tersebut. Hingga akhirnya,ia memutuskan untuk keluar dari "penjara" itu. ${ }^{2}$

Sekolah juga sering membebani anak didik dengan tugas rumah atau yang sering disebut PR. Dalam satu hari ada dua atau tiga guru memberikan PR masing-masing sepuluh soal. Hal ini bisa menjadikan anak tidak merasa fun dalam belajar karena dihadapkan pada kewajiban yang memaksa. Kesan lain dari sekolah formal adalah hanya disikapi sebagai lahan untuk mencari ijazah dan mencetak sarjana saja. Semua itu sebagian dari kelemahan sekolah, tetapi sekolah juga mempunyai peran yang penting dalam proses bersosialisasi dan mengembangkan diri. Seperti kata Syafinuddin al-Mandari bahwa sekolah yang mengungkung, membebani, menguras, maupun membius, bebarengan dengan suasana rumah yang tidak akrab dengan hawa keilmuan dan perilaku mulia, menjadikan anak ibarat bergantung pada dahan yang rapuh. ${ }^{3}$

Berdasarkan berbagai masalah di atas, maka muncullah berbagai alternatif pendidikan sebagai solusi untuk mencari format pendidikan yang baik untuk anak-anak. Salah satu yang sedang marak adalah homeschooling. Jika ditelusuri biografi para tokoh yang berpengaruh di masa lalu, sesungguhnya merekapun ditempa dengan pendidikan "di rumah", meskipun formatnya berbeda dengan yang sekarang, seperti Ki Hajar Dewantara dan Buya Hamka. Model pendidikan homeschooling ini tanggungjawabnya secara penuh berada di tangan orang tua, tidak diserahkan kepada pihak lain sebagaimana sekolah formal.

Berdasarkan uraian di atas, maka masalah pokok yang dibahas dalam tulisan ini adalah bagaimana model pendidikan homeschooling sebagai sebuah pendidikan al- 
ternatif? Untuk mengkaji secara teoritik pokok permasalahan tersebut maka penulis menjabarkan ke dalam beberapa sub masalah sebagai berikut: bagaimana konsep homeschooling?, bagaimana klasifikasi homeschooling?, bagaimana pelaksanaan homeschooling di Indonesia?, bagaimana homeschooling dalam perspektif perkembangan anak?

\section{KONSEP HOMESCHOOLING}

Homeschooling merupakan bahasa Inggris yang terdiri dari kata home dan school. Menurut kamus bahasa Inggris homeschooling merupakan bentuk kata kerja, homeschooling is to instruct (a pupil, for example) in an educational program outside of established schools, especially in the home. ${ }^{4}$ Homeschooling berarti membimbing (misalnya: seorang murid) dalam program pendidikan di luar sekolah umum, khususnya dilaksanakan di rumah.

Banyak istilah yang digunakan untuk menyebutkan homeschooling. Ada home education dan home-based learning/home-based education..$^{5}$ Home education is the education of children at home, typically by parents or guardians, rather than in a public or private school. ${ }^{6}$ (Pendidikan rumah adalah pendidikan bagi anak yang dilaksanakan di rumah, tidak seperti sekolah umum baik negeri/swasta, jenis pendidikan ini biasanya dilaksanakan dengan menitikberatkan peran orang tua atau pembimbing).

Selanjutnya pengertian home-based education dapat digambarkan dengan makna (a) sebuah komitmen bagi orang tua untuk mendidik anak-anaknya sendiri, (b) pendidikan berbasis keluarga dan biasanya orang tua sebagai pemimpinnya (tetapi kadang siswa juga sebagai pemimpin), (c) suasana yang kondusif untuk mencapai kemandirian, (d) secara umum tidak berada dalam kelas konvensional dan tidak disetting dalam suatu institusi. ${ }^{7}$

Istilah yang diperkenalkan oleh Kementerian Pendidikan dan Kebudayaan adalah sekolah rumah. Istilah ini juga digunakan oleh asosiasi homeschooling yang bernama ASAH PENA (Asosiasi Sekolah Rumah dan Pendidikan Alternatif Indonesia). Penggunaan terminologi sekolah rumah kelihatannya merupakan usaha penerjemahan dari homeschooling dengan memberi nama sekolah rumah. Persepsi yang paling umum terbentuk di masyarakat ketika mendengar istilah ini adalah bersekolah di rumah. Persepsi selanjutnya yang biasanya terbentuk adalah orang tua menjadi guru bagi anak-anaknya sendiri. Memang tidak salah dengan persepsi tersebut karena merupakan salah satu pengertian homeschooling. Pada hakekatnya homeschooling jauh lebih luas dari pada sekadar sekolah di rumah atau orang tua yang mendidik anaknya sendiri.

Salah satu pengertian umum homeschooling adalah sebuah keluarga yang memilih untuk bertanggung jawab sendiri atas pendidikan anak-anaknya dengan berbasis rumah. Pada homeschooling, orang tua bertanggung jawab sepenuhnya atas proses pendidikan anak; sementara pada sekolah reguler tanggung jawab itu didelegasikan kepada guru dan sistem sekolah. Walaupun orang tua menjadi penanggung jawab utama, akan tetapi pendidikan homeschooling tidak hanya dan tidak harus dilakukan 
orang tua sendiri. Selain dilakukan sendiri, orang tua juga bisa mengundang guru privat, mendaftarkan pada kursus, melibatkan anak-anak pada proses magang, dan sebagainya. Sesuai namanya homeschooling memang berpusat di rumah, tetapi proses homeschooling tidak hanya mengambil lokasi di rumah. Para orang tua homeschooling dapat menggunakan sarana apa saja dan di mana saja untuk pendidikan homeschooling anaknya.

Beberapa orang pemerhati pendidikan merumuskan homeschooling, antara lain: Ella Yulaelawati mengemukakan"homeschooling adalah proses layanan pendidikan yang secara sadar, teratur, dan terarah dilaksanakan oleh orang tua atau keluarga dan proses belajar mengajar pun berlangsung dalam suasana yang kondusif."8 Sri Utami Soedarsono Djamaluddin dikutip Hendrie Suheryana mengemukakan "homeschooling adalah pilihan program pendidikan yang fleksibel dan bervariasi yang mencerminkan adanya keanekaragaman manusia dalam memilih metode yang dipakai." 9 Sementara Sumardiono menjelaskan "homeschooling atau sekolah mandiri adalah ketika anak-anak tidak tergantung pada sistem sekolah formal yang ada sekarang, tetapi memutuskan sendiri (bersama orang tua sebagai mentornya) mengenal apa yang dipelajari, bagaimana cara belajar, waktu belajar dan di mana proses belajarnya."10

Homeschooling bisa jadi juga berupa instruksi/modul-modul yang diberikan di rumah namun tetap di bawah supervisi sekolah korespondensi/mitra (correspondence schools) sekolah yang menaungi (umbrella schools). Di beberapa tempat, anak-anak yang akan mengikuti homeschooling dituntut untuk mengikuti kurikulum yang disetujui secara legal. Filosofi homeschooling yang curriculum-free bisa jadi dianggap sebagai unschooling, suatu terma yang diciptakan pada tahun 1977 oleh tokoh pendidikan John Holt dalam majalahnya Growing Without Schooling. ${ }^{11}$

Berdasarkan beberapa pengertian di atas, dapat disimpulkan bahwa homeschooling merupakan alternatif pendidikan yang fleksibel, tidak kaku dalam proses belajarnya. Bagaimana cara atau metode belajar yang akan dipakai? Kapan waktu belajar? Di mana kegiatan belajar itu dilaksanakan? Semua itu disesuaikan dengan kondisi dan keadaan anak sehingga akan muncul perasaan fun dan nyaman dalam belajar. Anak juga dijadikan subjek dalam pembelajarannya, dan orang tua berperan sebagai penanggung jawab utama.

Berikut ini merupakan persamaan dan perbedaan homeschooling dengan sekolah regular, di antaranya:

\section{Persamaan}

1. Sekolah dan homeschooling merupakan model pendidikan anak.

2. Sekolah dan homeschooling bertujuan untuk mencari kebaikan bagi anak-anak.

3. Sama-sama dapat mengantarkan anak-anak pada tujuan pendidikan

\section{Perbedaan}

1. Sistem di sekolah terstandarisasi, sistem homeschooling customized sesuai dengan kebutuhan anak dan kondisi orang tua. 
2. Pengelolaan di sekolah terpusat (kurikulumnya diatur), pengelolaan homeschooling tergantung pada orang tua (orang tua memilih sendiri kurikulum dan materi ajar untuk anak).

3. Jadwal belajar di sekolah telah tertentu, jadwal belajar homeschooling tergantung kesepakatan orang tua dan anak.

4. Tanggung jawab pendidikan di sekolah didelegasikan orang tua kepada guru dan sekolah, pada homeschooling tanggung jawab sepenuhnya ada pada orang tua.

5. Peran orang tua di sekolah relatif minimal karena pendidikan dijalankan oleh sistem dan guru; pada homeschooling peran orang tua sangat vital dalam menentukan keberhasilan pendidikan anak.

6. Pada model belajar di sekolah, sistem sudah mapan dan orang tua tinggal memilih/mengikuti; pada homeschooling membutuhkan komitmen dan kreativitas orang tua untuk mendesain dan melaksanakan homeschooling sesuai kebutuhan anak.

Konsep homeschooling adalah mengembalikan suatu hal mendasar yaitu mengembalikan peran orang tua dan keluarga ke tempat yang semestinya karena di sanalah peran utama keluarga, khususnya seorang ibu dalam pertumbuhan dan perkembangan seorang anak. Dilihat dari ajaran Islam, anak merupakan karunia dan amanah Allah yang harus dijaga, dibina, dan dibimbing. Amanah wajib dipertanggungjawabkan. Tanggung jawab orang tua terhadap anak tidaklah kecil. Secara umum inti tanggung jawab itu ialah penyelenggaraan pendidikan bagi anak-anak dalam keluarga.

Orang tua merupakan pendidik pertama dan utama, mempunyai peranan yang penting untuk menolong pertumbuhan anak-anaknya, baik secara fisik maupun psikis. Anak dilahirkan dalam keadaan fitrah dan tergantung pada orang tualah untuk menjaga atau merusak fitrah itu. Rasulullah saw. bersabda:

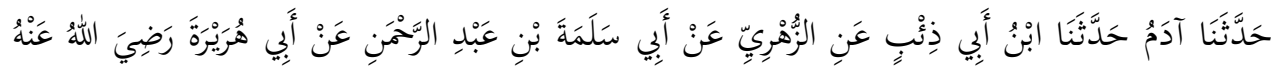

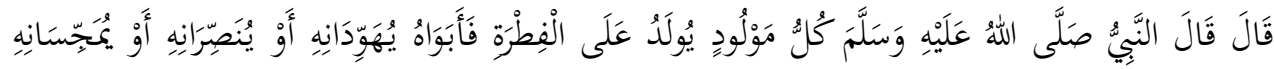

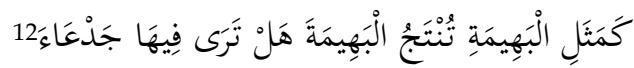

(Imam Bukhari berkata), telah menyampaikan berita kepada kami Adam, telah menyampaikan berita kepada kami Ibnu Abi Zi’bin, dari al-Zuhri, dari Abu Salamah bin 'Abd. Al-Rahman, dari Abu Hurairah ra berkata, Nabi saw. Bersabda: setiap anak dilahirkan dalam keadaan fitrah (suci), kedua orang tuanyalah yang menjadikan Yahudi atau Nasrani atau Majusi, bagaikan seekor binatang melahirkan anaknya, apakah engkau melihat dia melindunginya?

Ilmu pengetahuan, kesabaran, kasih sayang, dan ketulusan, serta tanggung jawab yang tinggi adalah modal untuk membawa diri dan keluarga pada keselamatan itu. ${ }^{13}$

Konsep homeschooling sama sekali tidak bertentangan dengan Islam, karena menuntut ilmu bisa dilakukan dimana saja, kapan pun dan kepada siapapun tidak diba- 
tasi oleh waktu, usia dan jenis kelamin. Oleh sebab itu, pendidikan bagi anak sangat diutamakan dan orang tua berkewajiban memelihara anak-anaknya dengan cara mendidik, menanamkan nilai keimanan, mengembangkan wawasan, dan mengajarkan akhlak mulia, serta menghindarkannya dari teman-teman yang berbudi pekerti buruk.

\section{KLASIFIKASI HOMESCHOOLING}

Berdasarkan jenisnya, homeschooling dibedakan menjadi tiga, yaitu homeschooling tunggal, homeschooling majemuk, dan komunitas homeschooling.

\section{Homeschooling Tunggal}

Jenis homeschooling ini dilaksanakan oleh orang tua dalam satu keluarga tanpa bergabung dengan lainnya. Biasanya homeschooling jenis ini diterapkan karena adanya tujuan dan alasan khusus yang tak dapat diketahui atau dikompromikan dengan komunitas homeschooling lain. Alasan lain, karena lokasi atau tempat tinggal si pelaku homeschooling yang tidak memungkinkan berhubungan dengan komunitas homeschooling lain.

\section{- Pengajar}

Bisa ayah, ibu, atau keduanya, tetapi jika keduanya sama-sama bekerja, harus ada pilihan lain, yaitu ada orang yang bisa dipercaya dan dapat mengelola kegiatan anak, baik itu tante, paman, nenek, atau anggota keluarga lain.

\section{- Kelebihan}

Anak bisa belajar kapan saja, di mana saja, dan dengan siapa saja.

\section{- Kekurangan}

Bila anak hanya menjalani kegiatan homeschooling di rumah (tidak bergabung dengan komunitas lain), dikhawatirkan berpengaruh pada kemampuan pergaulan atau sosialisasinya. Selain itu, anak juga tidak memiliki kesempatan untuk bersaing atau berkompetisi dengan orang lain.

\section{- Tantangan}

1. Sulitnya memperoleh dukungan atau tempat bertanya, berbagi, dan berbanding keberhasilan.

2. Kurangnya tempat sosialisasi untuk mengekspresikan diri sebagai syarat pendewasaan.

3. Orang tua harus melakukan penilaian hasil pendidikan dan mengusahakan penyetaraan. ${ }^{14}$

\section{Homeschooling Majemuk}

Homeschooling ini terdiri atas dua keluarga atau lebih.Untuk kegiatan tertentu dilaksanakan oleh dua keluarga atau lebih. Sementara kegiatan pokok tetap dilaksanakan oleh orang tua masing-masing. Alasannya, ada kebutuhan yang dapat dikompromikan oleh beberapa keluarga untuk melaksanakan kegiatan bersama.Misalnya kegiatan olah raga, musik/seni, sosial, ataupun kegiatan keagamaan. 


\section{- Pengajar}

Sama seperti homeschooling jenis tunggal, dilakukan orang tua.

\section{- Kelebihan}

Ruang gerak sosialisasi peserta didik lebih luas

\section{- Kelemahan}

Relatif tidak ditemui persoalan

\section{- Tantangan}

1. Perlu kompromi dan fleksibelitas jadwal, suasana, fasilitas, dan kegiatan tertentu.

2. Perlu ahli dalam bidang tertentu walaupun kehadiran orang tua harus tetap ada.

3. Anak-anak dengan keahlian atau kegiatan khusus harus menyesuaikan atau menerima lingkungan lainnya dan menerima perbedaan-perbedaan lainnya sebagai proses pembentukan jati diri.

4. Orang tua masing-masing penyelenggara homeschooling harus menyelenggarakan sendiri penyetaraannya. ${ }^{15}$

\section{Komunitas Homeschooling}

Jenis ini merupakan gabungan beberapa homeschooling majemuk yang menyusun dan menentukan silabus dan bahan ajar. Termasuk meramu kegiatan pokok (olah raga, seni dan bahasa), menyediakan sarana dan prasarana serta jadwal pembelajaran.

\section{- Pengajar}

Bisa orang tua, bisa juga orang lain yang mampu berperan sebagai fasilitator utama dalam kegiatan anak

\section{- Kelebihan}

1. Tersedia fasilitas pendukung pembelajaran yang lebih baik, seperti bengkel kerja, laboratorium alam, perpustakaan, fasilitas olah raga dan kesenian.

2. Dukungan yang lebih besar karena masing-masing bertanggung jawab untuk saling mengajar sesuai keahlian masing-masing.

\section{- Kekurangan}

Dikhawatirkan komunitas ini berubah menjadi sekolah formal, karena terstruktur atau terjadwal, seperti mengadakan kegiatan seminggu dua kali, dan sebagainya.

\section{- Tantangan}

1. Perlu kompromi dan fleksibelitas jadwal, suasana, fasilitas, dan kegiatan tertentu yang dapat dilaksanakan bersama-sama.

2. Perlunya pengawasan yang profesional sehingga perlu keahlian dalam bidang tertentu walaupun kehadiran orang tua harus tetap ada.

3. Anak-anak dengan keahlian atau kegiatan khusus harus menyesuaikan atau menerima lingkungan lainnya dan menerima perbedaan-perbedaan lainnya sebagai proses pembentukan jati diri. ${ }^{16}$

Ketiga jenis homeschooling tersebut dapat dipilih sesuai dengan tipe belajar anak. Karena setiap anak itu mempunyai kemampuan yang berbeda-beda. 


\section{PELAKSANAAN HOMESCHOOLING DI INDONESIA}

Konsep homeschooling ini sudah lama dikenal di Indonesia. Bahkan jauh sebelum sistem pendidikan barat datang. Di pesantren-pesantren misalnya, para kyai, buya, dan tuan guru secara khusus mendidik anak-anaknya sendiri. Saat ini sistem persekolahan di rumah juga bisa dikembangkan untuk mendukung program pendidikan kesetaraan. ${ }^{17}$

Dalam Undang-undang nomor 20 tahun 2003 tentang sistem pendidikan nasional (Sisdiknas) dalam pasal 27 ayat (1) dikatakan bahwa, "Kegiatan pendidikan informal yang dilakukan oleh keluarga dan lingkungan berbentuk kegiatan belajar secara mandiri". Lalu pada ayat (2) dikatakan bahwa, "Hasil pendidikan sebagaimana dimaksud dalam ayat (1) diakui sama dengan pendidikan formal dan nonformal setelah peserta didik lulus ujian sesuai dengan standar nasional pendidikan". Ini berarti Jadi secara hukum kegiatan homeschooling dilindungi oleh undang-undang. ${ }^{18}$

Perkembangan homeschooling di Indonesia juga dipengaruhi oleh akses terhadap informasi yang semakin terbuka dan membuat para orang tua punya banyak pilihan untuk pendidikan anak-anaknya. Upaya pemasyarakatan homeschooling tidak cukup diikuti dengan informasi yang berkenaan dengan persyaratan yang seharusnya dimiliki dalam menerapkannya. Akibatnya, praktek homeschooling menjadi berbeda, tidak dengan dasar pikiran yang tepat dan kuat.

Apabila sekolah rumah ini sudah merupakan kebutuhan utama bagi masyarakat, sebaiknya harus dipertimbangkan berbagai kondisi dan dampak yang dihasilkannya. Misalnya saja, harus disadari bahwa homeschooling memiliki kompleksitas yang lebih tinggi karena orangtua harus bertanggung jawab atas keseluruhan proses pendidikan anak. Harus diantisipasi berbagai kelemahan yang dikhawatirkan banyak orang berkenaan dengan ketrampilan sosial anak karena sekolah ini berpotensi menghasilkan keterampilan sosial yang relatif rendah, terutama dengan teman sebaya. Bisa jadi akan menimblkan resiko berkurangnya kemampuan bekerja dalam kelompok, kemampuan berorganisasi dan kemampuan memimpin. Proteksi berlebihan dari orang tua juga akan menyebabkan anak mengalami kesulitan untuk menyelesaikan situasi dan masalah sosial yang kompleks dan tidak terprediksi.

\section{HOMESCHOOLING DAN PERKEMBANGAN ANAK}

Memperbincangkan tentang bagaimana sebuah sekolah masa kini dapat meningkatkan perkembangan anak, maka bahasan tidak dapat terlepas dari berbagai perubahan dalam filosofi pendidikan yang terjadi sepanjang sejarah yang menyebabkan terjadinya perubahan dalam teori dan praktek pendidikan. Pendidikan yang mengandalkan "three $R$ " (reading, 'riting, dan 'rithmetic) ke metode "berpusat pada anak" yang berfokus pada minat anak. ${ }^{19}$ Saat ini banyak pendidikan yang merekomendasikan pengajaran anak pada tingkat awal dengan mengintegrasikan bidang yang berkaitan dengan subjek dan mendasarkan kepada minat dan bakat alamiah anak. Misalnya belajar membaca dan matematika dalam konteks proyek studi sosial, atau mengajarkan konsep matematika melalui studi musik. Mereka mendukung proyek kooperatif, me- 
nawarkan partisipasi aktif pemecahan masalah dan kooperasi rapat orang tua-guru. ${ }^{20}$ Banyak pendidik kontemporer yang juga menekankan " $\mathrm{R}$ " keempat, yaitu reasoning (penalaran). Anak-anak yang diajari keterampilan berpikir dalam konteks subjek akademis terbukti lebih baik dalam tes kecerdasan dan prestasi sekolah. Stenberg mengungkapkan bahwa siswa akan belajar lebih baik ketika diajari dengan berbagai macam cara, menekankan keterampilan kreatif dan praktis sekaligus mengingat dan berpikir kritis. ${ }^{21}$

Berbagai perubahan dalam teori dan praktek pendidikan tampaknya akan sulit dicapai pada model praktek pendidikan yang biasa ditemukan pada sekolah-sekolah formal di Indonesia. Para orangtua yang memiliki perhatian pada pendidikan anakanaknya pada umumnya menganggap bahwa model pendidikan yang tepat hanya mungkin diperoleh dari homeschooling, dimana mereka dapat mengatur sendiri kurikulum dan metode belajar yang mendekati ideal.

Disamping sumbangan positifnya terhadap perkembangan anak, ternyata kritik terbesar yang banyak diterima praktek homeschooling juga berkenaan dengan perkembangan anak, yaitu dalam hal kemampuan sosialisasi. Arif Rahman, mengatakan bahwa hal yang harus menjadi titik perhatian penting dari homeschooling adalah strategi untuk menghindari kekhawatiran bahwa siswa yang mengikuti metode pendidikan ini akan teralienasi dari lingkungan sosialnya sehingga potensi kecerdasan sosialnya tidak muncul. ${ }^{22}$ Kecemasan itu wajar mengingat lingkungan rumah yang sangat terbatas sehingga anak tidak terbiasa dengan perbedaan dan cenderung memahami sesuatu daari sudut pandangnya sendiri.

Hasil penelitian menunjukkan bahwa banyaknya siswa yang berasal dari Asia Timur yang berprestasi bagus di Amerika Serikat adalah karena pengaruh budaya dan praktik pendidikan di negara asal mereka. Hari dan tahun bersekolah yang lebih tinggi dibanding sekolah AS, kurikulum yang diatur secara sentral, kelas lebih besar (sekitar 40 - 50 murid), dan para guru menghabiskan lebih banyak waktu mengajari seluruh kelas, sedangkan anak AS lebih banyak waktu bekerja sendiri atau dalam kelompok kecil dan karena itu menerima perhatian yang lebih besar tetapi lebih sedikit instruksi total. ${ }^{23}$

Di sisi lain, hasil penelitian Taylor ${ }^{24}$ menunjukkan bahwa sangat sedikit siswa homeschooling yang mengalami masalah dalam berhubungan sosial. Menurutnya, berbagai kritik yang dilontarkan mengenai homeschooling berkenaan dengan kemampuan sosialisasi anak justru menghasilkan hal yang sebaliknya. Konsep diri yang positif yang diperoleh anak-anak dari pendidikan homeschooling ternyata mampu mendorong kemampuan sosialisasi yang baik.

\section{SIMPULAN}

1. Homeschooling adalah pendidikan yang dilakukan secara mandiri oleh keluarga, yang materi pembelajarannya dipilih dan disesuaikan dengan kebutuhan anak. Homeschooling merupakan pendidikan bagi anak-anak yang dilaksanakan di rumah dan secara khusus diberikan oleh orang tua atau seorang tutor profesio- 
nal. Homeschooling dalam praktiknya memindahkan sekolah dari area umum ke area yang lebih privat, yakni ke rumah.

2. Klasifikasi format homeschooling, yaitu: Homeschooling tunggal dilaksanakan oleh orang tua dalam satu keluarga tanpa bergabung dengan lainnya karena hal tertentu atau karena lokasi yang berjauhan. Sedangkan homeschooling majemuk Dilaksanakan oleh dua atau lebih keluarga untuk kegiatan tertentu sementara kegiatan pokok tetap dilaksanakan oleh orangtua masing-masing.

3. Pelaksanaan homeschooling di Indonesia yang juga disebut pendidikan di rumah merupakan pendidikan bagi anak-anak yang dilaksanakan di rumah dan secara khusus diberikan oleh guru atau seorang tutor profesional. Homeschooling dalam pengertian modern, merupakan alternatif pendidikan formal di negara-negara maju. Praktek homeschooling memindahkan sekolah dari area umum ke area yang lebih privat, yakni ke rumah. Perlu digarisbawahi disini, bahwa homeschooling tampaknya lebih direkomendasikan bagi negara yang sudah maju.

\section{CATATAN AKHIR:}

1. Hery Noer Aly dan H. Munzier S, Watak Pendidikan Islam, Jakarta: Friska Agung Insani, 2000, h. 197.

2. M. Izza Ahsin, Dunia Tanpa Sekolah, Cet. I; Bandung: Read, 2007, h. 30.

3. Syafinuddin al-Mandari, Rumahku Sekolahku, Jakarta: Pustaka Zahra, 2004, h. 4.

4. The Free Online Dictionary, "Definition of Homeschooling" http://www.Thefreedictionary.com/homeschool (20 Agustus 2016).

5. Sumardiono, "Pengertian Homeschooling", http://www.sumardiono.com/index.php?option $=$ com_content\&task=view\&id=287\&itemid=79 (20 Agustus 2016).

6. Wikipedia, "Homeschooling", http://en.wikipedia.org/wiki/homeschooling (20 Agustus 2016).

7. www.homeedsa.com, "Definition of Homeschooling" http://www.homeedsa.com/Article/HS\%20Teaching\%20Strategies.asp\#Definition\%20f\%20HS. (20 Agustus 2016)

8. News@indosiar.com, “Homeschooling: Sekolah Rumah atau Rumah Sekolah", http://news.indosiar.com/news_read.htm?id=60082 (20 Agustus 2016)

9. Hendrie Suheryana,"Home-Schooling Solusi Pendidikan Untuk yang Tidak Puas di Sekolah Formal", Tabloid Mom \& Kiddie, edisi 14, tahun 1, 12-25 Maret 2007, h. 12.

10. Sumardiono, "Homeschooling, Sekolah Rumah/Mandiri," http://www.sekolahrumah.com/ index.php?option $=$ com_content\&task $=$ category\&sactionied $=4 \&$ id $=13 \&$ itemid $=31(20$ Agustus 2016).

11. Chris Verdiansyah (ed). Homeschooling. Rumah Kelasku, Dunia Sekolahku, Jakarta: Penerbit Buku Kompas, 2007, h. ix.

12. Muhammad bin Ismail bin Ibrãhim bin al-Mugîrah al-Bukhãrî, Sahih al-Bukhãrî, CD alMaktabah al-Syamila Versi 2. 1, Juz 5, h. 182, nomor hadis 1296.

13. Maya Pujiati, "Mendidik Anak adalah Sebuah Investasi", Selasa 20 Desember 2005, http://my.opera.com/madrasah-keluarga/blog/show.dml/91758 (20 Agustus 2016)

14. Hilman, "Pilih-Pilih Homeschooling", Tabloid Nakita, No. 430/TH IX/30 Juni 2007, h. 7.

15. Hilman, "Pilih-Pilih Homeschooling", h. 7.

16. Hilman, "Pilih-Pilih Homeschooling", h. 7.

17. Chris Verdiansyah (ed).op.cit., h. 18-19. 
18. Chris Verdiansyah (ed). Ibid., h. 19.

19. RD. Feldman Papalia, DE., Old, SW., Human Development(New York-USA: McGraw-Hill, 2004), h. 334-335.

20. RD. Feldman Papalia, DE., Old, SW., ibid., h. 335.

21. RD. Feldman Papalia, DE., Old, SW., ibid., h. 335.

22. Chris Verdiansyah (ed)., op.cit., h. ix.

23. RD. Feldman Papalia, DE., Old, SW., op.cit., h. 337.

24. Wikipedia.org, Homeschooling, h. 13.

\section{DAFTAR PUSTAKA:}

Ahsin, M. Izza, Dunia Tanpa Sekolah, Cet. I; Bandung: Read, 2007.

Aly, Hery Noer dan H. Munzier S., Watak Pendidikan Islam, Jakarta: Friska Agung Insani, 2000.

Campbell, Linda, et al., Metode Praktis Pembelajaran Berbasis Multiple Intelligences, terj. Tim Intuisi Depok: Intuisi Press, 2006.

Departemen Agama Republik Indonesia, Al-Qur'an dan Terjemah, Jakarta: PT. Sygma Examedia Arkanleema, 2009.

Dwi R, Mutiara, "Belajar Tidak Harus di Sekolah Formal", Tabloid MomEKiddie, edisi 14, tahun 1, 12-25 Maret 2007, h. 14.

Griffith, Mary. Belajar Tanpa Sekolah: Bagaimana Memanfaatkan Seluruh Dunia sebagai Ruang Kelas Anak Anda, Bandung: Nuansa, 2005.

Hilman, "Pilih-Pilih Homeschooling", Tabloid Nakita, No. 430/TH IX/30 Juni 2007.

Jurnal Madrasah Kelurga, "Melirik Kembali Homeschooling", http://my.opera.com/ madrasahkeluarga/blog/melirik-kembali-homeschooling, (20 Agustus 2016).

Kurniasih, Imas. Homeschooling Bersekolah di Rumah Kenapa Tidak, Yogyakarta: Cakrawala, 2009.

Magdalena, Maria, Anakku Tidak Mau Sekolah Jangan Takut Cobalah Homeschooling, Jakarta: PT Gramedia Pustaka Utama, 2010.

Mandari, Syafinuddin al-Mandari, Rumahku Sekolahku, Jakarta: Pustaka Zahra, 2004.

Muhammad bin Ismail bin Ibra>him bin al-Mugi>rah al-Bukha>ri>, Sahih al-Bukha>ri>(CD alMaktabah al-Syamila Versi 2. 1), Juz 5, h. 182, nomor hadis 1296.

News@indosiar.com, "Homeschooling: Sekolah Rumah atau Rumah Sekolah", http://news. indosiar.com/news_read.htm?id=60082 (20 Agustus 2016)

Pujiati, Maya. "Mendidik Anak adalah Sebuah Investasi", Selasa 20 Desember 2005, http://my.opera.com/madrasah-keluarga/blog/show.dml/91758 (20 Agustus 2016)

RD. Feldman Papalia, DE., Old, SW., Human Development, New York-USA: McGraw-Hill, 2004, h. 334-335.

Republik Indonesia, Undang-Undang Republik Indonesia Nomor 20 Tahun 2003 tentang Sistem Pendidikan Nasional, Cet. IV; Jakarta: Sinar Grafika, 2011.

Suheryana, Hendrie, "Home-Schooling Solusi Pendidikan Untuk yang Tidak Puas di Sekolah Formal",Tabloid Mom \& Kiddie, edisi 14, tahun 1, 12-25 Maret 2007.

Sumardiono, "Homeschooling , Sekolah Rumah/Mandiri," http://www.sekolahrumah. com/index.php?option $=$ com_content\&task $=$ category\&sactionied $=4 \& \mathrm{id}=13 \&$ itemid $=31(20$ Agustus 2016).

Sumardiono, "Pengertian Homeschooling", http://www.sumardiono. com/index. php?option=com_content\&task=view\&id=287\&itemid=79 (20 Agustus 2016).

Sumardiono, Homeschooling: A Leap for Better Learning, Lompatan Cara Belajar, Jakarta: PT Elex Media Komputindo. 
The Free Online Dictionary, "Definition of Homeschooling" http://www.Thefreedictionary.com/homeschool (20 Agustus 2016).

Verdiansyah, Chris (ed), Homeschooling; Rumah Kelasku, Dunia Sekolahku, Jakarta: Penerbit Buku Kompas, 2007.

Wikipedia, "Homeschooling", http://en.wikipedia.org/wiki/homeschooling (20 Agustus 2016).

www.glorianet,org/mau/kliping/klipbers.html, dan http://fuadinotkamal. wordpress. com/2007/12/31/sekolah-sebagai-rumah-kedua/. (20 Agustus 2016).

www.homeedsa.com, "Definition of Homeschooling" http://www.homeedsa. com/ Article/HS\%20 Teaching\%20Strategies.asp\# Definition\%20f\%20HS. (20 Agustus 2016). 